\title{
Bone Marrow Gouty Tophi With Plasma Cell Myeloma
}

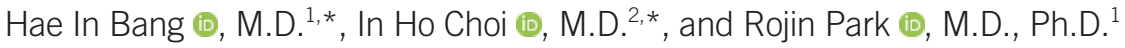 \\ Departments of ${ }^{1}$ Laboratory Medicine and ${ }^{2}$ Pathology, Soonchunhyang University Seoul Hospital, Seoul, Korea
}

\section{Dear Editor,}

Gout is a systemic disease characterized by recurrent, painful arthritis caused by the deposition of uric acid crystals [1]. Uric acid crystal deposition occurs in tissues when serum uric acid level rises above the normal threshold. The pathological threshold of uric acid for hyperuricemia is $0.40 \mathrm{mmol} / \mathrm{L}$ [2]. A deposit of uric acid crystals in patients with longstanding hyperuricemia is termed a tophus [3]. Gouty tophi generally occur at the first metatarsophalangeal joints, ears, and finger pulps; however, although rare, gouty tophi have also been reported at non-skeletal sites including the bronchi, mitral valve, liver, breasts, and even bone marrow (BM) [3-5]. To date, only two cases of gout involving the BM have been reported [4, 5], and neither of them was accompanied by other hematologic malignancies such as plasma cell myeloma (PCM). Therefore, we report the first case of gouty tophi in the BM of a patient with PCM. This study was approved by the Institutional Review Board of Soonchunhyang University Hospital, Seoul, Korea (IRB File No. 2019-04-002).

A 67-year-old woman, who had been receiving dialysis for four yrs owing to monoclonal gammopathy of undetermined significance and end-stage renal disease, was admitted to the Soonchunhyang University Hospital, Seoul, for an evaluation of frequent catheter occlusion. She also complained of severe pain in the distal interphalangeal joints in both hands. The initial laboratory findings were as follows: hemoglobin, $94 \mathrm{~g} / \mathrm{L}$ (reference range, $120-160 \mathrm{~g} / \mathrm{L})$; white blood cell count, $7.1 \times 10^{9} / \mathrm{L}$ (4.0$\left.10.0 \times 10^{9} / \mathrm{L}\right)$; platelet count, $146 \times 10^{9} / \mathrm{L}\left(130-450 \times 10^{9} / \mathrm{L}\right)$; pro- thrombin time (PT), 9.9 seconds (9.3-11.6 seconds); activated partial thromboplastin time (aPTT), 32.0 seconds (27.8-41.7 seconds); fibrinogen, $2.95 \mathrm{~g} / \mathrm{L}(2.09-3.77 \mathrm{~g} / \mathrm{L}) ;$ D-dimer, 9,812 $\mu \mathrm{g} / \mathrm{L}(0-243 \mu \mathrm{g} / \mathrm{L})$; anti-thrombin, 26\% (65-129\%); protein C, $59 \%$ (70-148\%); free protein S, 58.8\% (69.4-138.3\%); blood urea nitrogen (BUN), $17.11 \mathrm{mmol} / \mathrm{L}$ (2.14-7.14 mmol/L); serum creatinine, $431.40 \mu \mathrm{mol} / \mathrm{L}$ (44.20-106.08 $\mu \mathrm{mol} / \mathrm{L}) ;$ uric acid, $0.30 \mathrm{mmol} / \mathrm{L}(0.14-0.42 \mathrm{mmol} / \mathrm{L}) ;$ total protein, $50 \mathrm{~g} / \mathrm{L}$ (64-83 g/L); albumin, 16 g/L (35-52 g/L); lgG, 8.96 g/L (7.00-16.00 g/L); IgA, $1.81 \mathrm{~g} / \mathrm{L}$ (0.70-4.00 g/L); IgM, $0.88 \mathrm{~g} / \mathrm{L}(0.40-2.30 \mathrm{~g} / \mathrm{L}) ;$ free light kappa chain, $0.13 \mathrm{~g} / \mathrm{L}(0.03-0.19 \mathrm{~g} / \mathrm{L})$; free light lambda chain, $10.39 \mathrm{~g} / \mathrm{L}(0.05-0.26 \mathrm{~g} / \mathrm{L})$; free light kappa chain/free light lambda chain ratio, 0.12 (0.26-1.65); and $\beta 2$-microglobulin, 2,412.67 nmol/L (84.82-203.56 nmol/L).

Serum protein electrophoresis revealed two monoclonal peaks in the gamma region and immunofixation electrophoresis confirmed the presence of double gammopathy, IgG-lambda. The level of monoclonal protein was $6.6 \mathrm{~g} / \mathrm{L}$. Eight days after admission, the uric acid level increased to $0.52 \mathrm{mmol} / \mathrm{L}$. A BM aspirate smear showed that plasma cells accounted for $45.2 \%$ of all nucleated cells, and a BM section revealed focally infiltrated plasma cells with multiple uric acid crystals (gouty tophi) with foreign body reaction (Fig. 1). Immunophenotypic analysis revealed that the plasma cells were CD19-, CD56dim+, and CD45- and showed cytoplasmic lambda light chain restriction (tumor burden: $31.5 \%$ ). No apparent cytogenetic abnormalities were found by FISH for t(4;14)(p16;q32), t(14;16)(q32;q23),
Received: October 30, 2019

Revision received: December 23, 2019

Accepted: March 20, 2020

Corresponding author: Rojin Park, M.D., Ph.D.

Department of Laboratory Medicine, Soonchunhyang University Seoul Hospital, 59 Daesaqwan-ro, Yongsan-gu, Seoul 04401, Korea

Tel: +82-2-709-9427, Fax: +82-2-710-3088, E-mail: rpark@schmc.ac.kr

*These authors equally contributed to this study.

\section{(c) (i) (8)}

\section{(C) Korean Society for Laboratory Medicine}

This is an Open Access article distributed under the terms of the Creative Commons Attribution Non-Commercial License (https://creativecommons.org/licenses/by-nc/4.0) which permits unrestricted non-commercial use, distribution, and reproduction in any medium, provided the original work is properly cited. 

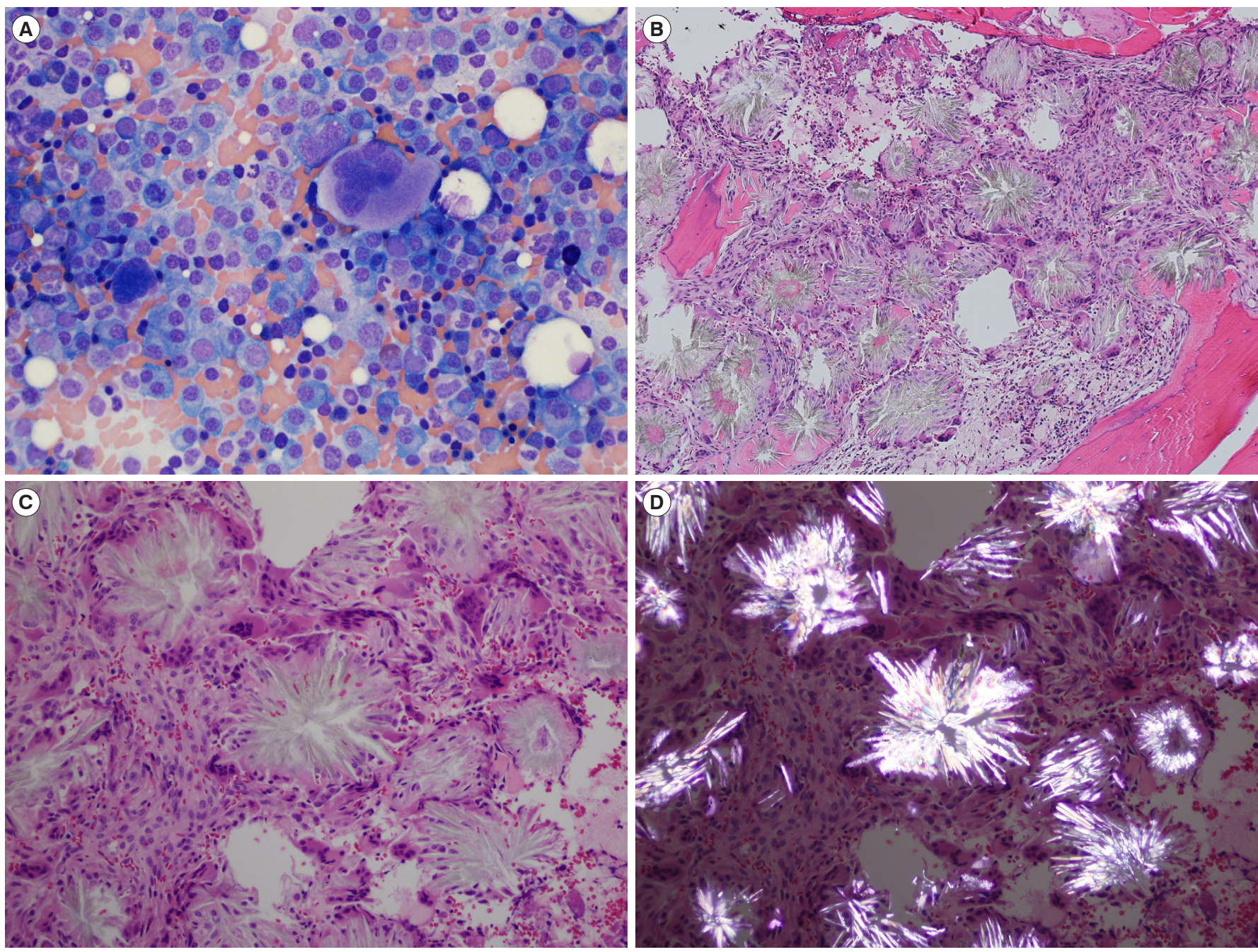

Fig. 1. Bone marrow (BM) aspirate smear and biopsy findings. (A) Plasma cells on the BM aspirate smear (Wright-Giemsa stain, $\times 400)$. (B, C) Fine, needle-shaped, radially oriented crystals surrounded by foreign-body type giant cells on the BM section (hematoxylin and eosin stain, $\times 100$ and $\times 200$ ). (D) Shiny, strong negatively birefringent crystals against a dark background observed by birefringence microscopy, consistent with uric acid crystals (hematoxylin and eosin stain, $\times 200$ ).

Table 1. Clinical manifestations of reported BM gouty tophi

\begin{tabular}{|c|c|c|c|c|c|c|}
\hline Published cases & Underlying disease & Present illness & Reason for BM study & BM Diagnosis & Treatment & Disease course \\
\hline Choi et al. [4] & $\begin{array}{l}\text { HTN, ESRD, } \\
\text { hypothyroidism }\end{array}$ & $\begin{array}{l}\text { Pain in nodules and } \\
\text { plaques on extremities }\end{array}$ & Anemia, Neutropenia & BM gouty tophi only & $\begin{array}{l}\text { Allopurinol, Colchicine, } \\
\text { Prednisolone }\end{array}$ & $\begin{array}{l}\text { Renal: aggravated } \\
\text { Skin: stationary }\end{array}$ \\
\hline Agarwaal et al. [5] & $\begin{array}{l}\text { Gout, Hepatitis C } \\
\text { infection }\end{array}$ & $\mathrm{NI}$ & $\begin{array}{l}\text { Leukopenia, } \\
\text { Thrombocytopenia }\end{array}$ & BM gouty tophi only & $\mathrm{NI}$ & $\mathrm{NI}$ \\
\hline Present case & MGUS, ESRD & $\begin{array}{l}\text { Catheter occlusion, Pain } \\
\text { in hand joints }\end{array}$ & $\begin{array}{l}\text { Anemia, For evaluation } \\
\text { of MGUS }\end{array}$ & $\begin{array}{l}\text { Plasma cell myeloma } \\
\text { with BM gouty tophi }\end{array}$ & $\begin{array}{l}\text { Bortezomib, Melphalan, } \\
\text { Prednisone }\end{array}$ & Died after 1st CTx \\
\hline
\end{tabular}

Abbreviations: BM, bone marrow; HTN, hypertension; ESRD, end stage of renal disease; MGUS, monoclonal gammopathy of undetermined significance; NI, not informed; CTx, chemotherapy.

$\mathrm{t}(11 ; 14)(\mathrm{q} 13 ; \mathrm{q} 32), 17 \mathrm{p} 13$ deletions, 1q gains, and chromosome 13 abnormalities and the chromosomal analysis was also normal. The patient was diagnosed as having symptomatic PCM with gout and was started on a treatment regime of bortezomib, melphalan, and prednisone. However, 10 days after chemotherapy was initiated, the patient died of uncontrolled acute gastro- 
intestinal bleeding induced by disseminated intravascular coagulation (DIC). Clinical manifestations of our case along with those of the previously reported cases are summarized in Table 1.

Hyperuricemia can occur owing to overproduction of uric acid through liver metabolism and cell turnover or underexcretion by the kidneys and gut [1,2]. Although hyperuricemia is a classic feature of gout, blood uric acid levels can be normal during an attack [6], as in our case. In general, gouty tophi have a predilection for the distal parts of the body because of distal circulatory stasis [7]. Increased plasma cells near the BM vascular niche in myeloma patients might cause circulatory stasis and uric acid deposition [8]. In addition, a tophus is a chronic inflammatory granulomatous response to uric acid crystals. Monocytes engulfing uric acid crystals can release proinflammatory cytokines, such as interleukin $1 \beta$ and tumor necrosis factor $\alpha$, and induced neutrophils can also play a role in tophus formation [1-3]. These inflammatory reactions in patients with gout can also increase thrombotic tendencies [8, 9], which might have led to the DIC state in our patient.

We believe that PCM patients with gouty tophi in the BM should be better cared for because of the increased possibility of thrombotic tendency during treatment. Further clinical studies are needed to optimize treatment strategies for the patients with clinical process like our case.

\section{ACKNOWLEDGEMENTS}

None declared.

\section{AUTHOR CONTRIBUTIONS}

RP conceived the study, HIB and IHC contributed to the interpretation of the results, and all authors contributed to writing the manuscript.

\section{CONFLICTS OF INTEREST}

None declared.

\section{RESEARCH FUNDING}

This work was supported by Soonchunhyang University Research funding.

\section{ORCID}

Hae In Bang

https://orcid.org/0000-0001-7854-3011

In Ho Choi

https://orcid.org/0000-0002-1551-6849

Rojin Park

https://orcid.org/0000-0003-2866-037X

\section{REFERENCES}

1. Richette P and Bardin T. Gout. Lancet 2010;375:318-28.

2. Dalbeth N, Merriman TR, Stamp LK. Gout. Lancet 2016;388:2039-52.

3. Chhana A and Dalbeth N. The gouty tophus: a review. Curr Rheumatol Rep 2015;17:19.

4. Choi CM, Lew BL, Lee SH, Sim WY. Gouty panniculitis also involving the bone marrow. Acta Derm Venereol 2013;93:189-90.

5. Agarwaal A, Green L, Thiagarajan P. Gouty tophi in the bone marrow. Br J Haematol 2016;172:9.

6. Ragab G, Elshahaly M, Bardin T. Gout: An old disease in new perspective - A review. J Adv Res 2017;8:495-511.

7. Noll JE, Williams SA, Purton LE, Zannettino AC. Tug of war in the haematopoietic stem cell niche: do myeloma plasma cells compete for the HSC niche? Blood Cancer J 2012;2:e91.

8. Huang CC, Huang PH, Chen JH, Lan JL, Tsay GJ, Lin HY, et al. An independent risk of gout on the development of deep vein thrombosis and pulmonary embolism: a nationwide, population-based cohort study. Medicine (Baltimore) 2015;94:e2140.

9. Kubota Y, McAdams-DeMarco M, Folsom AR. Serum uric acid, gout, and venous thromboembolism: the atherosclerosis risk in communities study. Thromb Res 2016;144:144-8. 